\title{
Does the Sino-US Trade Friction Promote Firm Innovation? The Role of the Export Grab Effect
}

\author{
Zhen $\mathrm{Xu}{ }^{1}$, Xin Zhong ${ }^{1, *}$ and Zhongyan Zhang ${ }^{2}$ \\ 1 Business School, Beijing Normal University, Beijing 100875, China; zhenxu@mail.bnu.edu.cn \\ 2 Department of Economics and Management, Taiyuan Institute of Technology, Taiyuan City 030008, China; \\ 201831410011@mail.bnu.edu.cn \\ * Correspondence: 03022@bnu.edu.cn
}

Citation: Xu, Z.; Zhong, X.; Zhang, Z. Does the Sino-US Trade Friction Promote Firm Innovation? The Role of the Export Grab Effect.

Sustainability 2022, 14, 2709. https:// doi.org/10.3390/su14052709

Academic Editors: Elkhan Richard Sadik-Zada and Andrea Gatto

Received: 29 January 2022

Accepted: 23 February 2022

Published: 25 February 2022

Publisher's Note: MDPI stays neutral with regard to jurisdictional claims in published maps and institutional affiliations.

Copyright: () 2022 by the authors Licensee MDPI, Basel, Switzerland. This article is an open access article distributed under the terms and conditions of the Creative Commons Attribution (CC BY) license (https:/ / creativecommons.org/licenses/by/ $4.0 /)$.

\begin{abstract}
We examine and explain changes of firm innovation following the Sino-US trade frictions. Specifically, we use the unique microdata of Chinese technology and innovation firms from 2016 to 2019 to identify the response of firm innovation to the shock of the Sino-US trade friction and investigate the changes in firm innovation before and after the outbreak of the Sino-US trade friction. We found that, on average, export firms significantly increased innovation after the Sino-US trade friction. In particular, firms in the advanced manufacturing industry perform significantly better than firms in other technical fields. To explain this phenomenon, we compare firms' export performance in different technical fields and conduct a detailed mechanism test. It is found that the Sino-US trade friction has led to the export grab phenomenon in some technical fields, and the export grab effect is the reason for the significant increase in the innovation of export firms. The direct effect of export grab promotes the innovation of sustainable export firms, and the indirect effect of export grab leads to an increase in innovation by reducing the threshold of the export market. We verified the direct and indirect effects of export grab on firm innovation following the Sino-US trade frictions.
\end{abstract}

Keywords: Sino-US trade friction; export grab effect; firm innovation

\section{Introduction}

Innovation is a sustainable driving force for economic development [1], but the current international economic situation poses great challenges to innovative firms. Since the beginning of 2018, a series of adjustments of import tariffs by China and the United States have exposed the global economy to the great risks of trade policy uncertainty [2]. According to recent advances in trade policy uncertainty literature, the elimination of trade policy uncertainty benefits innovation [3-5]. Previous empirical studies have verified this using Chinese data at both the firm level and industry level [6,7]. Obviously, the theory reveals that there is an inverse linear relationship between trade policy uncertainty and innovation, which means that the rise of trade policy uncertainty will impair innovation. Therefore, does this indicate that the Sino-US trade frictions will damage the innovation of Chinese firms?

We find that trade policy uncertainty literature does not explain changes in Chinese firms' innovation following the Sino-US trade frictions, at least in the comparatively short term. By using the unique microdata of Chinese technology and innovation firms from 2016 to 2019 , we find that export firms have significantly increased innovation after the outbreak of the Sino-US trade friction, which is evidently not in line with the internal logic of trade policy uncertainty literature. Further research also found that although the high-tech field is the focus of the Sino-US trade friction, the innovation performance of export firms in the advanced manufacturing industry shows an unusually prominent growth after the Sino-US trade friction. However, it seems difficult for the existing literature to make a reasonable explanation for such a phenomenon. The literature on competitive pressure in export 
markets may possibly explain this: the Sino-US trade friction intensifies the competitive pressure of export firms facing external markets [8], and escaping the competition effect may make such firms increase research and development (R\&D) investment and innovation activities [9-11] to obtain greater market share and profits in the future [12].

However, the dataset used in this paper fails to reveal the competitive pressure in the export market faced by firms; in contrast, it shows that export firms in some technical fields have exceptionally prominent export performance after the Sino-US trade friction. For example, in the advanced manufacturing industry, which has outstanding innovation performance after the trade friction, the annual average export volume of its firms has increased by approximately twice as much as that before the trade friction, and the export share of total income has also increased significantly. Obviously, these indicators are not sufficient to help us obtain a sense of the pressure in the export market when firms are facing adverse shocks. However, by comparing the differences in exports of firms in different technical fields before and after the Sino-US trade friction, we find that those technical fields that have significantly increased innovation after the Sino-US trade friction are often accompanied by comparatively more prominent export business growth, while exports in the technical fields that do not have increased innovation after the Sino-US trade friction are generally not well performing and even have negative growth. Therefore, is this a coincidence?

In fact, after the outbreak of the Sino-US trade friction, Chinese firms have an obvious phenomenon of export grab. According to the annual statistics of China's National Bureau of Statistics, China's exports increased by $7.05 \%$ in 2018. Additionally, at the press conference in December 2018, a spokesman for China's Ministry of Commerce said that China's imports and exports achieved rapid growth in 2018. Empirical studies in the literature also reveal the existence of the export grab effect of the Sino-US trade frictions. For example, Xie and Wang [13] found that the Sino-US trade friction can promote the short-term export of products by using monthly data at the product level. Zhang et al. [14] verified the existence of the export grab effect of the Sino-US trade friction by using product-level custom data. Cavallo et al. [15] compared the commodity data of importers and retailers in the United States and found that after the Sino-US trade friction, importers increased their imports from China in the short term and expanded their inventory as much as possible to cope with the risk of further tariff increases in the future.

Export grab is a manifestation of the reallocation effect of the Sino-US trade friction on export firms. By probing into the export behaviour of firms in different technical fields, we find that firms in certain technical fields show an obvious export-grab phenomenon after the outbreak of the Sino-US trade friction, while others do not, and they even suffer a great export shrinkage. Theoretically, the export grab effect comes from the demand shock in the international commodity market. Foreign buyers overdraw their future demand to avoid the risk of future market uncertainty, resulting in a sharp rise in the demand for Chinese products in the short term, which may have two effects. The first is the direct effect. For firms that continue to export, due to the effect of economies of scale, the increase in output caused by demand expansion in the short term will reduce their marginal cost, and then the increased productivity will enable capable firms to carry out innovation activities $[16,17]$. The second is called the indirect effect. The shock of foreign demand leads to an insufficient supply of domestic sustainable exporters. As a result, export grab reduces the threshold for domestic firms to enter the export market, which will affect firms' entry and exit, export decision making and innovation [16]. The empirical study of this paper verifies that the direct effect and indirect effect of export grab are the mechanism of the increase in innovation of export firms after the Sino-US trade friction and explains the phenomenon that export firms increase innovation after the Sino-US trade friction.

The possible contributions of this paper are as follows: First, we use unique microdata of Chinese technology and innovation firms to provide new evidence that the Sino-US trade friction stimulates firms' innovation. Although previous studies have discussed trade friction and innovation $[18,19]$, they have not yet formed a unified conclusion. In contrast 
to these studies, we use more detailed microdata of technology and innovative firms and take the outbreak of the Sino-US trade friction in 2018 as an exogenous shock. It is found that, on average, export firms increase innovation after the Sino-US trade friction. Second, we explain a new mechanism of trade friction affecting firm innovation, which is also the most important innovation of this paper. Wei and Liu [18] believe that trade friction has a compelling effect, which leads to an increase in firm innovation. We creatively find that the export grab effect is the reason for the increase in export firm innovation after the Sino-US trade friction. Third, this paper enriches the research on the relationship between exports and firm innovation. Studies in the field of trade have shown that exports could benefit firm innovation and technological upgrading $[16,17,20,21]$. We verify the significance of exports to firm innovation again.

The structure of the rest of the text is arranged as follows after the introduction part: the second part reviews the relevant literature; the third part introduces the empirical design and data; the fourth part reports the empirical benchmark results, the effectiveness test and robustness test of identification; the fifth part shows the results of the heterogeneity test and tests the export grab mechanism; the sixth part summarizes the entire text.

\section{Literature Review}

Since the purpose of this article is to test the response of firm innovation to the Sino-US trade friction, and explain the increase in firm innovation following the Sino-US trade friction from the perspective of export grab, we arrange our literature review as follows: We first review the relevant theories of trade friction and literatures evaluating the effects of trade friction in Section 2.1. We then summarize the main theoretical literature on the relationship between export and innovation in Section 2.2.

\subsection{Related Economic Effects of the Sino-US Trade Frictions}

The Sino-US trade friction represents the return of the United States to trade protectionism [22]. Discussions on trade protectionism in international economics have a long tradition and form a series of rich theories, but trade protectionism theories from different periods have different policy objectives due to the different economic contexts. According to the development context of trade protectionism theory, early mercantilism believed that primitive wealth could be accumulated by restricting imports and expanding exports, while List's infant industrial protection theory believed that trade policy did not need to restrict the import of all industries, and restrictions on agricultural products should be relaxed, while policies should be protected for promising industries [23]. However, when trade protection theory developed in the 1980s, technology transfer and technology restriction became an important part of the theory [24,25]. New trade protection theory and strategic trade protection theory believe that developed countries need to intervene in trade behaviour and restrict the trade of high-tech products by using policies such as technical barriers and intellectual property protection to reduce technology transfer from developed countries to developing countries and safeguard their international competitive advantage and interests [26,27].

However, free trade theory holds that large-scale trade frictions will hurt both sides. Quantitative studies based on this Sino-US trade friction have also verified this point. For example, in Chinese literature, the research of Li et al. shows that the increase in US tariffs will damage the welfare level of both China and the United States. In addition, the employment, import and export of the two countries will be damaged to a certain extent [28]. Lv et al. compared the economic effects of the strategic adjustment on both China and the United States. The study found that the Sino-US trade friction will reduce the scale of the Sino-US trade on a large scale, especially imports of the United States from China, which will be greatly damaged. However, compared to the United States, China's welfare loss will be more serious in trade frictions [29]. Cui et al. also confirmed the above view. Furthermore, they believe that China's retaliatory tariff will aggravate China's welfare loss in trade frictions [30]. In the United States, Amiti et al. studied the 
price mechanism of the impact of tariff increases on welfare in the United States and found that tariffs in the United States increase the pricing level and mark-ups of the American manufacturing industry and reduce the variety of products consumed by consumers, and that retaliatory tariffs from other countries will make American consumers face serious welfare losses [31]. Similarly, the research of Fajgelbaum et al. shows that the impact of tariff increases in the Sino-US trade frictions will fully penetrate the United States through the import price effect and will be absorbed by American consumers and import firms. In general, the United States will face serious welfare losses [22]. Cavallo et al. once again verified the price effect of tariffs on U.S. welfare with U.S. product level data. From the analysis of Chinese and American economists, it can be found that trade frictions will damage the overall welfare of China and the United States [15].

In addition to the macrolevel analysis of the Sino-US trade friction, the microlevel investigation in the literature also reveals that there is an obvious export grab effect following the Sino-US trade friction. For example, Xie and Wang verified that trade frictions have the effect of export grabbing by using monthly data at the product level, and that the Sino-US trade frictions can promote the short-term export of products [13]. Zhang et al. verified the existence of the export grab effect of trade friction by using data on customs products before and after the Sino-US trade friction [14]. Moreover, data from the United States also prove that trade frictions have an export grab effect in at least some specific industries. Cavallo et al. found that after the Sino-US trade friction, importers have increased their imports from China in the short term and expanded their inventory as much as possible to cope with the risk of further tariff increases in the future. Moreover, compared with Chinese firms exporting to the United States, American firms exporting to China have obvious price reduction behaviour in the face of China's retaliatory tariffs [15].

Therefore, what is the impact of trade friction on firm innovation? No clear and unified conclusion has been reached for this problem in the literature. For example, Wei and Liu used the data of China's listed companies from 2003 to 2016 to measure the trade environment uncertainty faced by firms by the number of trade frictions in the industry and studied the relationship between trade environment uncertainty and firm innovation [18]. The conclusion shows that trade environment uncertainty has a positive effect on firm innovation. The greater the uncertainty of the trade environment is, the higher the innovation of firms in the industry. In contrast, the research of Wan et al. shows that the Sino-US trade frictions will reduce the international R\&D level of Chinese firms [19]. Therefore, the effect of trade friction on innovation is not generalized and should be analysed in detail.

\subsection{Export Grab Effect and Firm Innovation}

However, the export grab induced by the Sino-US trade friction may potentially lead to firm innovation. Although the relationship between export grab and firm innovation has not been addressed in the literature, there have been many discussions on the relationship between exports and innovation in the field of trade in recent years. First, exports have a learning effect. Export firms can improve technology and promote innovation through export learning. Many studies have verified the export learning effect $[21,32,33]$. On the one hand, the export learning effect affects firm innovation through economies of scale. Exports help in expanding firms' production, and then the role of economies of scale can be further brought into play, which will reduce the marginal cost of firms [20], and promote firm performance [32], and is reflected as productivity gains [34]. Therefore, with increasing performance, firms have an incentive to upgrade their technology, generating an export promotion technological upgrading effect [17]. On the other hand, the export learning effect can be improved through communication with foreign customers. This effect is particularly obvious for export firms in developing countries. Export firms learn from customers or competitors through export behaviour so that their productivity or technical level can be improved [10,21,35-38]. Second, exports have a selective effect. Engaging in innovation is conducive to increasing the productivity level of firms, allowing them to self-select in export 
markets [34,39]. Indeed, some firms that prefer to enter export markets will undertake ex ante R\&D to achieve access to export markets [40], while sustainable exporters will also engage in innovative activities due to competitive pressures in international markets [8] to avoid being eliminated or losing market share in competitive markets [12]. Moreover, the shock of export demand will have a reallocation effect on export firms [11]. On the one hand, the demand expansion in foreign markets will increase the innovation rent of firms and stimulate the innovation investment behaviour of firms; on the other hand, the expansion of foreign demand reduces the threshold of the export market, and new export firms improve the competitive atmosphere of the export market, which also encourages firms' innovation behaviour. However, the shock of foreign demand tends to affect larger firms at the forefront of technology and may play a smaller role in promoting the innovation of new firms.

In fact, the phenomenon of export grabbing following the Sino-US trade friction is a reflection of the impact of foreign demand shocks. To hedge against the risk of further increases in future trade costs, foreign buyers overdrew future demand, which manifested itself in a sharp short-term rise in Chinese export volumes. Based on the above literature review, this paper theoretically argues that this will have two effects on exporters' innovation $[11,16]$. The first is the direct effect. The expanded export demand reduces the marginal cost of firms, promotes firm productivity and expands firm performance. Firms have the ability and motivation to carry out innovation activities and upgrade technology to obtain more market share and innovation rent in the future. The second is the indirect effect. The shock of foreign demand will change the distribution of firms and have a reallocation effect on domestic export firms, allowing new exporters to enter the export market and generate an export learning effect. Exports will be reallocated to larger firms, and innovation will converge with exporters at the technological frontier, thus leading to an overall increase in the level of innovation among exporters. This paper uses unique data on national technology and innovation firms from 2016 to 2019 to study the impact of the SinoUS trade frictions on firm innovation and verifies the direct and indirect effect mechanisms of firm innovation caused by export grabs following the Sino-US trade frictions.

\section{Identification Strategy and Data}

\subsection{Identification Strategy}

In this paper, the treatment group and the control group are divided according to whether the firm is an exporter or not. The control group is non-exporters, and the treatment group is exporters; that is, firms with exports in any period of the sample are defined as export firms in all periods to identify the differential responses of firms in different groups to the shock of the Sino-US trade friction, comparing the changes in firm innovation before and after the Sino-US trade friction. The specific identification equation is as follows:

$$
\ln (\text { Innovation })_{f i t}=\alpha+\beta_{1} * E X P_{f i} *{\text { Post } 18_{t}}_{t} X_{f t} * \beta_{2}+X_{i t} * \beta_{3}+v_{f}+\text { Year }_{t}+\varepsilon_{f i t}
$$

where subscript $f$ means firm, $i$ indicates the industry to which the enterprise belongs, and $t$ indicates the year. The explained variable $\ln (\text { Innovation })_{f i t}$ indicates the innovation level of firms. The explanatory variable $E X P_{f i} * \operatorname{Pos}_{t} 18_{t}$ is the interaction of a firm's export status $E X P_{f i}$ and the 2018 Sino-US trade friction shock variables Post $18_{t}$. EXP $P_{f i}$ takes 1 as exporters and 0 as non-exporters. Post $18_{t}$ takes 1 indicates years after the outbreak of the 2018 Sino-US trade friction and takes 0 otherwise. The coefficient of primary interest to us is $\beta_{1}$, which measures the innovation performance difference between export firms and non-export firms after being impacted by the Sino-US trade friction. $X_{f t}$ and $X_{i t}$ represent the firm-level and industry-level control variables, respectively, which are used to control the firm characteristics and industry characteristics over time; $v_{f}$ is a firm-level fixed effect, which is used to control firm heterogeneity that does not change over time; Year $r_{t}$ is the year fixed effect, which is used to control the interference of time factors on identification; and $\varepsilon_{f i t}$ is the error term. In addition, we also cluster the standard error according to the four-digit code of the Chinese industry. 
It should be noted that, first, we divide the treatment group and the control group because we consider the selective effect of the export market. The Sino-US trade friction may affect the choice of firms to enter and exit the export market. The way we divide the treatment and control groups can fix the impact of the effect of firms entering and exiting the export market based on the results to a certain extent. Second, although export firms are intuitively more likely to be impacted by the Sino-US trade frictions, we cannot deny that non-export firms are not affected during the process of the Sino-US trade frictions. In identifying the effect of Sino-US trade friction on the innovation of exporting firms, using non-exporting firms as a control group requires an examination of whether exporting and non-exporting firms are comparable; therefore, we will verify in the identification validity below that there is a parallel trend between the two after controlling for as many potential influences as possible. Third, this paper chooses the beginning of 2018 as the shock time node of the Sino-US trade friction because the first import tariff increase of the United States was in January 2018; however, the "301" survey of the United States in 2017 may have had an impact on Chinese innovative firms. Therefore, setting 2018 as the shock node may only underestimate the effect of the Sino-US trade friction on firm innovation. In other words, if setting 2018 as the impact node can identify the effect of the Sino-US trade friction on firm innovation, we have reasons to believe that the real effect may be greater.

\subsection{Data and Indicators}

The empirical research mainly uses our unique mircodata of Chinese technology and innovation firms. This dataset is jointly investigated and recorded by China's National Bureau of Statistics and China's Ministry of Science and Technology. The respondents are technological and innovative firms in most cities of mainland China. The variables involved cover four categories of information: basic information of firms, economic overview of firms, employees of firms and intellectual property rights of firms. The data cover a wide range of industries, including many subindustries under agriculture, manufacturing and service industries. We select subsamples of tradable sectors of the manufacturing industry in the dataset. The sample year is 2016-2019, just two years before and after the Sino-US trade friction in 2018, which can be used to identify the changes in firm innovation before and after the Sino-US trade friction.

We use the logarithm of the number of intellectual property rights granted to a firm in the current year plus one as a measure of firm innovation $\ln (\text { Innovation })_{f i t}$. The number of intellectual property rights granted in the current year can more accurately measure the innovation of a firm, which is the real output of the firms' innovation activities. In the robustness test, we also construct the innovation index based on the number of firms intellectual property applications as the explanatory variable. Moreover, we try to control the characteristics of firms as much as possible; hence, we mainly include registered capital $\left(\operatorname{lnCapital}_{f i t}\right)$, number of employees $\left(\operatorname{lnEmployment}{ }_{f i t}\right), \mathrm{R} \& \mathrm{D}$ investment $\left(\ln R D_{f i t}\right)$, angel investment $\left(\ln A n g e l_{f i t}\right)$, and firm age $\left(\ln A g e_{f i t}\right)$. In addition, this paper also adds the type of firm taxpayer $\left(\right.$ Type $\left._{f i t}\right)$, technical field $\left(\right.$ Field $\left._{f i t}\right)$, whether it is a graduated firm $\left(\right.$ Graduate $\left._{\text {fit }}\right)$, and whether it is a high-tech firm $\left(\right.$ Hightech $\left._{\text {fit }}\right)$ in the regression.

Considering that import competition, export demand and domestic competition may affect firm innovation, we also control for the above potential effects at the industry level. First, we use China's import volume by industry (InImport ${ }_{i t}$ ) and import growth rate $\left(\right.$ Imp_rate $\left._{i t}\right)$ to control import competition. Second, we use China's export volume by industry $\left(\operatorname{lnExport}_{i t}\right)$ and export growth rate $\left(\right.$ Exp_rate $\left._{i t}\right)$ to control the impact of changes in export demand on firm innovation. Third, this paper uses the industry-level average profits of scaled Chinese industrial firms (lnInd_Competition ${ }_{i t}$ ) as a proxy variable to measure domestic industry competition, and it can control the effect of domestic market competition.

Finally, we combine the above data to obtain an unbalanced panel dataset with 157,475 observation samples with a time span of 2016-2019. The descriptive statistics of the relevant indicators are shown in Table 1. 
Table 1. Descriptive statistics of the main variables.

\begin{tabular}{|c|c|c|c|c|}
\hline Variable & Mean & $\begin{array}{l}\text { Standard } \\
\text { Error }\end{array}$ & Minimum & Maximum \\
\hline $\ln (\text { Innovation })_{\text {fit }}$ & 0.280 & 0.626 & 0 & 7.067 \\
\hline$E X P_{f i} *$ Post $18_{t}$ & 0.029 & 0.168 & 0 & 1 \\
\hline $\operatorname{lnCapital}_{f i t}$ & 7.661 & 1.552 & -4.605 & 23.49 \\
\hline InEmployment $_{\text {fit }}$ & 2.658 & 0.971 & 0 & 10.65 \\
\hline $\ln R D_{f i t}$ & 2.951 & 3.036 & 0 & 14.86 \\
\hline $\ln$ ngel $_{\text {fit }}$ & 0.433 & 1.743 & 0 & 14.05 \\
\hline $\ln A g e_{f i t}$ & 1.324 & 0.746 & 0 & 4.745 \\
\hline Type fit & 1.350 & 0.477 & 1 & 2 \\
\hline Field $_{f i t}$ & 3.577 & 2.763 & 1 & 12 \\
\hline Graduate $_{\text {fit }}$ & 1.755 & 0.430 & 1 & 2 \\
\hline Hightech $_{\text {fit }}$ & 0.130 & 0.337 & 0 & 1 \\
\hline $\ln$ Export $_{i t}$ & 11.45 & 1.062 & 7.191 & 12.89 \\
\hline Exp_rate $i t$ & 0.053 & 0.080 & -0.197 & 0.335 \\
\hline $\operatorname{lnImport}_{i t}$ & 11.05 & 1.095 & 7.455 & 13.06 \\
\hline Imp_rate $i t$ & 0.052 & 0.129 & -0.222 & 3.013 \\
\hline InInd_Competition $_{i t}$ & -1.854 & 0.565 & -3.049 & 2.166 \\
\hline
\end{tabular}

\section{Empirical Results}

\subsection{Benchmark Regression Results}

The benchmark regression will test the heterogeneous responses of the innovation behaviour of export firms and non-export firms to the Sino-US trade friction, comparing the changes in the innovation differences between export firms and non-export firms before and after the Sino-US trade friction, and then analysing whether export firms have strengthened innovation following the Sino-US trade friction.

The results are reported in Table 2. Column (1) only contains explanatory variables in the regression, with individual fixed effects and time fixed effects, and the estimated explanatory variable coefficient is 0.115 , which is significant at the significance level of $1 \%$, meaning that after the Sino-US trade friction, export firms have increased innovation compared with non-export firms. On this basis, Column (2) adds control variables at the firm level. Although the estimated coefficient of $E X P_{f i} * \operatorname{Post}_{t} 8_{t}$ is lower than Column (1), it is still significantly positive, indicating that after the occurrence of the Sino-US trade friction, export firms have better innovation performance than non-export firms.

Columns (3)-(5) further control the potential impact of foreign demand, import competition and domestic competition at the industry level on the basis of Column (2). Specifically, Column (3) further adds the logarithm of the industry's export volume and the industry's export growth rate to control the impact of the foreign demand shock. The estimated coefficient of $E X P_{f i} * \operatorname{Post}_{t} 8_{t}$ is still significantly positive, and the coefficients of industry-level foreign demand shock variables are not significant, which shows that export demand does not affect firm innovation. Similarly, Column (4) adds the logarithm of industry import volume and industry import growth rate to control the impact of import industry competition. The coefficient of $E X P_{f i} *$ Post $_{1} 8_{t}$ is still significantly positive, and the coefficients of import competition variables are not significant, indicating that industry-level import competition has not impacted firm innovation under the Sino-US trade frictions. Column (5) further controls the potential effect of domestic competition. The estimated coefficient of $E X P_{f i} * P_{0 s t} 18_{t}$ is still significantly positive, and the coefficient of InInd_Competition ${ }_{i t}$ is still not significant, indicating that domestic industry competition has not had a significant impact on firm innovation. Column (6) contains all control variables. The estimated coefficient of $E X P_{f i} *$ Post $_{1} 8_{t}$ is still significantly positive, which is in accordance with the previous estimation results. Therefore, after controlling all potential factors affecting firm innovation as much as possible, we find that export firms strengthen innovation after the Sino-US trade friction more than non-export firms. 
Table 2. Benchmark regression results.

\begin{tabular}{|c|c|c|c|c|c|c|}
\hline & (1) & (2) & (3) & (4) & (5) & (6) \\
\hline \multirow[t]{2}{*}{$E X P_{f i} *$ Post $18_{t}$} & $0.115^{* * *}$ & $0.082 * * *$ & $0.086^{* * *}$ & $0.086 * * *$ & $0.082 * * *$ & $0.086^{* * *}$ \\
\hline & $(0.022)$ & $(0.023)$ & $(0.024)$ & $(0.024)$ & $(0.023)$ & $(0.024)$ \\
\hline \multirow[t]{2}{*}{$\operatorname{lnCapital}_{\text {fit }}$} & & 0.004 & 0.004 & 0.004 & 0.004 & 0.004 \\
\hline & & $(0.004)$ & $(0.004)$ & $(0.004)$ & $(0.004)$ & $(0.004)$ \\
\hline \multirow[t]{2}{*}{ InEmployment $_{\text {fit }}$} & & $0.082^{* * *}$ & $0.082 * * *$ & $0.082 * * *$ & $0.082 * * *$ & $0.082^{* * *}$ \\
\hline & & $(0.006)$ & $(0.006)$ & $(0.006)$ & $(0.006)$ & $(0.006)$ \\
\hline \multirow[t]{2}{*}{$\ln R D_{f i t}$} & & $0.024^{* * *}$ & $0.024^{* * *}$ & $0.024^{* * *}$ & $0.024^{* * *}$ & $0.024^{* * *}$ \\
\hline & & $(0.001)$ & $(0.001)$ & $(0.001)$ & $(0.001)$ & $(0.001)$ \\
\hline \multirow[t]{2}{*}{$\ln _{A n g e l}$ fit } & & $0.012^{* * *}$ & $0.011^{* * *}$ & $0.011^{* * *}$ & $0.012^{* * *}$ & $0.011^{* * *}$ \\
\hline & & $(0.003)$ & $(0.003)$ & $(0.003)$ & $(0.003)$ & $(0.003)$ \\
\hline \multirow[t]{2}{*}{$\ln A g e_{f i t}$} & & $0.099^{* * *}$ & $0.101^{* * *}$ & $0.101^{* * *}$ & $0.099^{* * *}$ & $0.101^{* * *}$ \\
\hline & & $(0.013)$ & $(0.013)$ & $(0.013)$ & $(0.013)$ & $(0.013)$ \\
\hline \multirow{2}{*}{ Type $_{f i t}$} & & $-0.035^{* * *}$ & $-0.036^{* * *}$ & $-0.036^{* * *}$ & $-0.035^{* * *}$ & $-0.036^{* * *}$ \\
\hline & & $(0.010)$ & (0.010) & (0.010) & $(0.010)$ & $(0.010)$ \\
\hline \multirow[t]{2}{*}{ Field $_{f i t}$} & & 0.003 & 0.004 & 0.004 & 0.003 & 0.004 \\
\hline & & $(0.003)$ & $(0.003)$ & $(0.003)$ & $(0.003)$ & $(0.003)$ \\
\hline \multirow[t]{2}{*}{ Graduate $_{\text {fit }}$} & & $0.036^{* * *}$ & $0.036^{* * *}$ & $0.035^{* * *}$ & $0.036^{* * *}$ & $0.036^{* * *}$ \\
\hline & & $(0.010)$ & $(0.010)$ & $(0.010)$ & $(0.010)$ & $(0.010)$ \\
\hline \multirow{2}{*}{ Hightech $_{\text {fit }}$} & & $0.162^{* * *}$ & $0.161^{* * *}$ & $0.161^{* * *}$ & $0.163^{* * *}$ & $0.161^{* * *}$ \\
\hline & & $(0.015)$ & $(0.015)$ & $(0.015)$ & $(0.015)$ & $(0.015)$ \\
\hline \multirow[t]{2}{*}{$\ln E$ xport $_{i t}$} & & & -0.002 & & & -0.007 \\
\hline & & & $(0.007)$ & & & $(0.008)$ \\
\hline \multirow[t]{2}{*}{ Exp_rate $_{i t}$} & & & 0.007 & & & -0.005 \\
\hline & & & $(0.054)$ & & & $(0.055)$ \\
\hline \multirow[t]{2}{*}{ InImport ${ }_{i t}$} & & & & 0.006 & & 0.009 \\
\hline & & & & $(0.006)$ & & $(0.008)$ \\
\hline \multirow[t]{2}{*}{ Imp_rate $_{i t}$} & & & & 0.023 & & 0.020 \\
\hline & & & & $(0.025)$ & & $(0.024)$ \\
\hline \multirow[t]{2}{*}{ InInd_Competition ${ }_{i t}$} & & & & & 0.015 & 0.010 \\
\hline & & & & & $(0.011)$ & $(0.011)$ \\
\hline \multirow[t]{2}{*}{ _cons } & $0.295^{* * *}$ & $-0.215^{* * *}$ & $-0.190 * *$ & $-0.282 * * *$ & $-0.188^{* * *}$ & $-0.208^{* *}$ \\
\hline & $(0.001)$ & $(0.043)$ & $(0.094)$ & $(0.080)$ & $(0.051)$ & $(0.098)$ \\
\hline Individual FE & yes & yes & yes & yes & yes & yes \\
\hline Year FE & yes & yes & yes & yes & yes & yes \\
\hline $\mathrm{N}$ & 157,475 & 134,869 & 131,953 & 131,953 & 134,869 & 131,953 \\
\hline $\mathrm{R}^{2}$ & 0.620 & 0.641 & 0.640 & 0.640 & 0.641 & 0.641 \\
\hline
\end{tabular}

Note: the dependent variable, firm innovation, is indexed by $\log$ (number of firm intellectual property granted +1 ) The independent variable is $E X P_{f i} * \operatorname{Post} 18_{t}$. Column (1) contains only the independent variable. Column (2) controls all individual control variables. Column (3) further adds the export volume and export growth rate at the industry level to control the impact of industry-level foreign demand shocks. Column (4) further adds industry-level import volume and import growth rate to control import competition shock. Column (5) adds domestic industry competition to control for the impact of the domestic market competition effect. Column (6) contains all individual and industry control variables. All regressions control both individual and year fixed effects (FE). Standard errors are clustered at the four-digit code of the Chinese industry. *** ** indicate significance levels of $1 \%$ and $5 \%$, respectively. $\mathrm{N}$ stands for the number of observations and $\mathrm{R}^{2}$ indicates the fitness of the model.

In short, the benchmark regression results show that after the outbreak of the Sino-US trade friction, export firms have increased innovation. Compared with non-exporters, exporters have evident innovation growth after being shocked by trade frictions. Based on the regression results in Column (6), on average, after the Sino-US trade friction, export firms have increased by $0.086 \%$ compared with non-export firms in the innovation measured by intellectual property rights granted. The rest of this section will verify whether export firms and non-export firms are comparable before trade friction and verify the robustness of the benchmark regression results.

\subsection{Validation of Identification}

The following methods will be used to test the effectiveness of the above identification. The results are reported in Table 3. 
Table 3. Effectiveness test of identification.

\begin{tabular}{|c|c|c|c|c|}
\hline & (1) & (2) & (3) & (4) \\
\hline$E X P_{f i} *$ Post $18_{t}$ & & & $\begin{array}{c}0.090^{* * *} \\
(0.031)\end{array}$ & $\begin{array}{c}0.069^{* * *} \\
(0.025)\end{array}$ \\
\hline$E X P_{f t} *$ Post $17 t$ & $\begin{array}{l}-0.040 \\
(0.032)\end{array}$ & & & \\
\hline$E X P_{f t} * Y R 2017_{t}$ & & $\begin{array}{c}0.014 \\
(0.023)\end{array}$ & & \\
\hline$E X P_{f t} * Y R 2018_{t}$ & & $\begin{array}{c}0.099^{* * * *} \\
(0.026)\end{array}$ & & \\
\hline$E X P_{f t} * Y R 2019_{t}$ & & $\begin{array}{c}0.107^{* * *} \\
(0.030)\end{array}$ & & \\
\hline $\begin{array}{c}\text { Control } \\
\text { variables }\end{array}$ & yes & yes & yes & yes \\
\hline Individual FE & yes & yes & yes & yes \\
\hline Year FE & yes & yes & yes & no \\
\hline City * Year FE & no & no & no & yes \\
\hline $\mathrm{N}$ & 35,242 & 131,953 & 56,460 & 131,872 \\
\hline $\mathrm{R} 2$ & 0.732 & 0.641 & 0.714 & 0.652 \\
\hline
\end{tabular}

Note: The placebo test in Column (1) uses the samples of two years before the shock (2016-2017) to test whether the treatment group and the control group are comparable before trade friction. Column (2) replaces the explanatory variable with the intersections of the export state variable and year dummy variables to test the change in innovation difference between export firms and non-export firms over time. Column (3) regression was carried out using only the samples of the two years before and after the shock node (2017-2018). Column (4) further adds the city cross-year fixed effect (FE) to exclude the potential impact of time-varying city characteristics. Column (1)-(3) control both individual and year fixed effects (FE). Standard errors are clustered at the four-digit code of the Chinese industry. ${ }^{* * *}$ indicates significance levels of $1 \%$. N stands for the number of observations and $\mathrm{R}^{2}$ indicates the fitness of the model.

\subsubsection{Placebo Test}

Column (1) reports the results of a placebo test, which was conducted by using a subsample of the two years before the occurrence of the Sino-US trade friction in 2018. The purpose is to test whether the innovation difference between export firms and non-export firms also changes significantly over time before the shock. In the specification, we first take the beginning of 2017 as the node to generate a time indicator, Post $17_{\mathrm{t}}$. Then, we interact it with export status variables to generate the placebo variable, $E X P_{f t} *$ Post $_{17}$. We replace the independent variable $E X P_{f i} * P_{o s t} 18_{t}$ in the benchmark regression by $E X P_{f t} * \operatorname{Post}_{1} t_{t}$, combined with using samples from 2016 and 2017 in the regression. The result in Column (1) shows that the estimated coefficient of $E X P_{f t} * P_{0 s t 17}$ is not statistically significant, indicating that after controlling all individual and industry control variables, the innovation difference between export firms and non-export firms has not changed significantly in approximately the year 2017; that is, the innovation of export firms and non-export firms is comparable before the Sino-US trade friction.

\subsubsection{More Flexible Estimates}

Column (2) adopts a more flexible identification method, replacing the independent variable in the benchmark estimation by a series of interactions of export status indicator and year dummy. The results show that the coefficient of $E X P_{f t} * Y R 2017_{t}$ is not significant, which shows that before the Sino-US trade friction in 2018, the innovation of export firms and non-export firms has a parallel trend, while the coefficients of both $E X P_{f t} * Y R 2018_{t}$ and $E X P_{f t} * Y R 2019_{t}$ are significantly positive, indicating that after the Sino-US trade friction in 2018, the innovation difference between export firms and non-export firms began to appear. As time passes, export firms tend to have more innovation than non-export firms.

\subsubsection{Two-Phase Panel Estimation}

Column (3) regresses the model using samples from the years before and after the SinoUS trade frictions (2017 and 2018). If the result is similar to the benchmark regression, we 
can then verify that the above benchmark regression results are effective to some extent. The results show that the coefficient of $E X P_{f i} * P_{o s t} 18_{t}$ is still significantly positive. Combined with the result of the placebo test, it can be inferred that around the beginning of 2018, the innovation difference between export firms and non-export firms began to increase significantly, and export firms strengthened innovation more than non-export firms.

\subsubsection{Controlling the Fixed Effect of City Cross Year}

Potential time-varying city features may affect the identification. To eliminate the influence of this factor and verify the effectiveness of the benchmark regression results, Column (4) further replaces the year fixed effect with the city cross-time fixed effect. The results show that the coefficient of $E X P_{f i} * P_{0 s} t 8_{t}$ is still significantly positive, which shows that the potential city characteristics over time do not interfere with the basic empirical results of this paper.

\subsection{Robustness Check}

The results of robustness tests are reported in Table 4. Column (1) excludes the firms that do not have any innovation behaviour in the sample period. Column (2) selects a subsample of high-tech firms only. Column (3) controls the impact of possible tax incentives on firm innovation. Column (4) constructs the dependent variable with the number of intellectual property right applications and re-estimates the model.

Table 4. Robustness test.

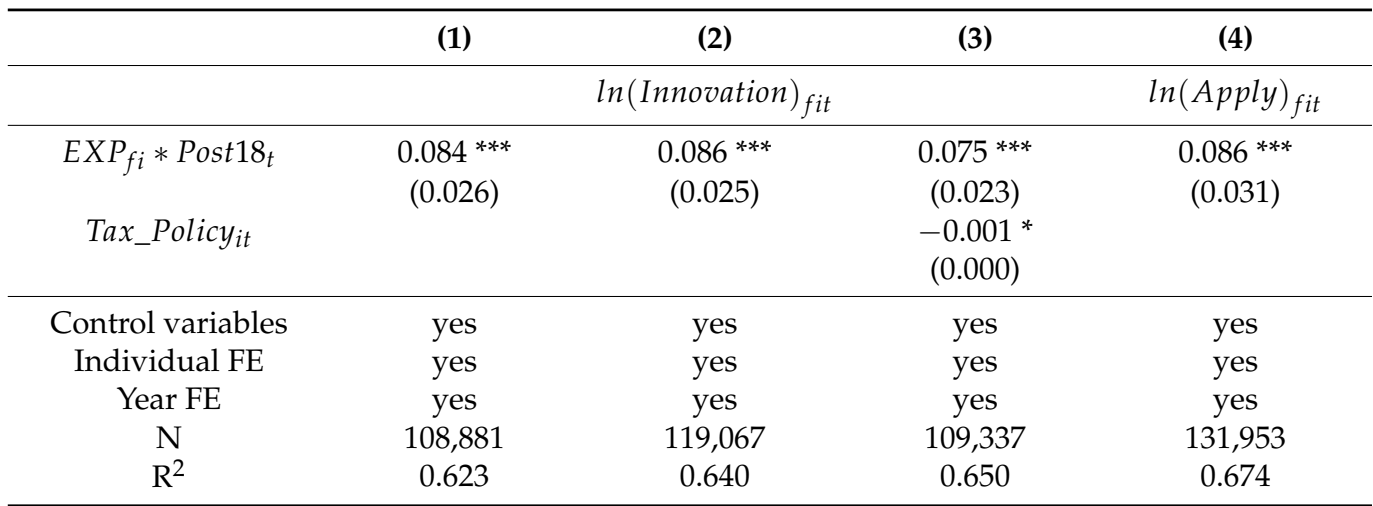

Note: Column (1) excludes the firms without innovative behaviour and only retains the firms with innovative behaviour. Column (2) only includes firms in high-tech industries, and Column (3) controls for the potential impact of tax incentives on firm innovation. Column (4) replaces the explanatory variable with log (number of intellectual property applications +1$)$ in the regression. All regressions control both individual and year fixed effects (FE). Standard errors are clustered at the four-digit code of the Chinese industry. ${ }^{* * *}, *$ indicate significance levels of $1 \%$ and $10 \%$, respectively. $\mathrm{N}$ stands for the number of observations and $\mathrm{R}^{2}$ indicates the fitness of the model.

\subsubsection{Excluding Firms without Innovation Activity}

Considering that there are some noninnovative firms in non-export firms, the average innovation level of non-export firms is lowered, which may interfere with the identification. To eliminate this impact, Column (1) excludes the firms that have no innovation activities in the data within four years, that is, the firms that have no R\&D investment, no intellectual property application granted within four years, and we re-estimate the model. The result shows that the coefficient of $E X P_{f i} * P_{o s t} 18_{t}$ is still significantly positive. Under this sub-sample, the basic result of this paper is robust.

\subsubsection{Re-Estimating with Sub-Sample of High-Tech Firms}

High-tech firms are one of the focuses of the Sino-US trade frictions. Firms in industries with high scientific and technological content are more likely to be influenced by adverse shocks in foreign markets, which may reduce their innovation activities after trade frictions. At the same time, firms in other industries may continue to innovate without 
obvious impact, resulting in an increase in the innovation of the whole sample on average. Therefore, there may be opposite conclusions on the regression results of different subsamples. Considering those potential effects, we exclude observations in comparatively low skill-intensive sectors, including textile, beverage, wood, etc., according to the Chinese industry classification. Column (2) regresses the model with the sample of industries with relatively high technology. The result shows that the coefficient of $E X P_{f i} * P_{o s t} 18_{t}$ is still significantly positive, indicating that the result of this paper is robust under the high-tech sub-sample.

\subsubsection{Controlling the Impact of Tax Incentives}

Preferential tax policies for firms are an important tool for the government to subsidize firms. Specifically, the preferential tax policies for firms within the sample years may affect the estimated results; that is, the innovation may come from the support of tax policies. To control the impact of preferential tax policies, this paper uses the annual actual tax payment of firms over firm income as the proxy variable of preferential tax policies. The specific indicators of preferential tax policies for firms are as follows:

$$
\text { Tax_Policy } y_{i t}=\frac{\operatorname{tax}_{i t}}{\text { income }_{\text {it }}} \text {. }
$$

Tax_Policy $y_{i t}$ measures the degree of tax preference. $\operatorname{tax}_{i t}$ is the actual tax paid by the firm in the current year, and income $e_{i t}$ is the total income of the firm. The larger Tax_Policy is, the smaller the firm will enjoy preferential tax policies, and vice versa. Column (3) reports the regression results. The coefficient of Tax_Policy $y_{i t}$ is -0.001 , which is significant at the significance level of $10 \%$, indicating that preferential tax policies have a positive impact on firm innovation. On average, firms with strong tax preferential policies support tend to have higher innovation output. However, according to the estimated coefficient, the effect of tax policy on firm innovation is comparatively small. At the same time, after controlling for preferential tax policies, the coefficient of $E X P_{f i} * P_{o s t} 18_{t}$ is still significantly positive, which shows that the results of this paper are robust.

\subsubsection{Using the Number of Intellectual Property Applications as the Independent Variable}

The number of intellectual property applications is also one of the indicators used to measure firm innovation. Column (4) uses the logarithm of the number of intellectual property applications plus 1 as the explanatory variable to re-estimate the model. The results show that the coefficient of $E X P_{f i} * P_{o s t} 18_{t}$ is still significantly positive, which shows that after the Sino-US trade friction, export firms have more intellectual property applications than non-export firms. This result also verifies once again that the results of this paper are robust.

\section{Discussion on Heterogeneity and Mechanism}

Through the previous analysis, we find that after the shock of the Sino-US trade friction, export firms have significantly increased innovation. In this section, we divide our sample by different technical fields to test the different performance of firm innovation after the Sino-US trade friction. More importantly, we will explain the reasons for the increased innovation of export firms after the Sino-US trade friction and the heterogeneity of the impact of the Sino-US trade friction on firm innovation in different technical fields.

\subsection{Technical Field Heterogeneity}

We divide the sample by different technical fields, as indicated by the dataset, to identify the heterogeneous innovation performance of export firms in different technical fields after the impact of the Sino-US trade friction. Specifically, the survey data used in this paper record firms' technical fields that belong to the following 12 categories, including: advanced manufacturing industry, modern transportation industry, biomedicine and medical devices, new materials, electronic information, aerospace, new energy and energy 
conservation, environmental protection, geospatial space and ocean, nuclear application technology, modern agriculture and others. This enables us to regress with sub-samples of each technical field separately. On the one hand, it helps to deeply explore the impact of the Sino-US trade friction on firm innovation in different technical fields. On the other hand, it further verifies the robustness of the empirical results from the response of firms in different fields to the Sino-US trade frictions. See Table 5 for specific test results.

Table 5. Technical field heterogeneity.

\begin{tabular}{|c|c|c|c|c|c|c|}
\hline & (1) & (2) & (3) & (4) & (5) & (6) \\
\hline & $\begin{array}{c}\text { Advanced } \\
\text { Manufacturing }\end{array}$ & $\begin{array}{c}\text { Modern } \\
\text { Transportation }\end{array}$ & $\begin{array}{c}\text { Biomedicine } \\
\text { and Medical } \\
\text { Devices }\end{array}$ & New Material & $\begin{array}{c}\text { Electronic } \\
\text { Information }\end{array}$ & Aerospace \\
\hline \multirow[t]{2}{*}{$E X P_{f i} *$ Post $18_{t}$} & $0.097^{* * *}$ & $0.616^{* *}$ & $0.102 *$ & 0.129 * & -0.013 & -0.024 \\
\hline & $(0.032)$ & $(0.242)$ & $(0.061)$ & $(0.072)$ & $(0.052)$ & $(0.119)$ \\
\hline \multirow{7}{*}{$\begin{array}{c}\text { Control variable } \\
\text { Individual FE } \\
\text { Year FE } \\
\text { N } \\
\mathrm{R}^{2}\end{array}$} & yes & yes & yes & yes & yes & yes \\
\hline & yes & yes & yes & yes & yes & yes \\
\hline & yes & yes & yes & yes & yes & yes \\
\hline & 50,705 & 998 & 19,829 & 14,079 & 24,699 & 1705 \\
\hline & 0.652 & 0.713 & 0.630 & 0.635 & 0.652 & 0.608 \\
\hline & (7) & (8) & (9) & (10) & (11) & (12) \\
\hline & $\begin{array}{l}\text { New Energy } \\
\text { and Energy } \\
\text { Conservation }\end{array}$ & $\begin{array}{c}\text { Environmental } \\
\text { Protection }\end{array}$ & $\begin{array}{c}\text { Geospatial } \\
\text { Space and } \\
\text { Ocean }\end{array}$ & $\begin{array}{c}\text { Nuclear } \\
\text { Application } \\
\text { Technology }\end{array}$ & $\begin{array}{c}\text { Modern } \\
\text { Agriculture }\end{array}$ & Other \\
\hline \multirow[t]{2}{*}{$E X P_{f i} *$ Post $18_{t}$} & 0.014 & -0.101 & 0.049 & 0.000 & -0.088 & 0.106 \\
\hline & $(0.142)$ & $(0.137)$ & $(0.092)$ & $()$. & $(0.235)$ & $(0.074)$ \\
\hline Control variables & yes & yes & yes & yes & yes & yes \\
\hline Individual FE & yes & yes & yes & yes & yes & yes \\
\hline Time FE & yes & yes & yes & yes & yes & yes \\
\hline $\mathrm{N}$ & 4538 & 4278 & 224 & 105 & 3431 & 1755 \\
\hline $\mathrm{R}^{2}$ & 0.673 & 0.633 & 0.838 & 0.608 & 0.649 & 0.617 \\
\hline
\end{tabular}

Note: The above table examines the impact of the Sino-US trade friction on firm innovation in different technical fields divided according to the survey data. We arrange the order of different technical fields in the table according to the significance of the regression coefficients. All regressions control both individual and time fixed effects (FE) Standard errors are clustered at the four-digit code of the Chinese industry. $* * * * *, *$ indicate significance levels of $1 \%, 5 \%$ and $10 \%$, respectively. $\mathrm{N}$ stands for the number of observations and $\mathrm{R}^{2}$ indicates the fitness of the model.

The heterogeneity test results in Table 5 mainly reflect the following characteristics: First, the innovation performance of the advanced manufacturing industry is outstanding after the Sino-US trade frictions. Column (1) shows that the regression coefficient of $E X P_{f i} * \operatorname{Post}_{1} 8_{t}$ is significantly positive, which indicates that export firms in the advanced manufacturing industry have significantly increased innovation than non-export firms after the shock of the Sino-US trade friction. Comparing the results in other technical fields, it can be found that the innovation of export firms in the advanced manufacturing industry has increased most significantly after the impact of the Sino-US trade friction, which means that firms' innovation in the advanced manufacturing industry has a relatively greater response to the Sino-US trade friction. Second, the results estimated by using samples of the modern transportation industry, biomedicine and medical devices, and new material technology also show that after the Sino-US trade friction, export firms have increased innovation compared to non-export firms, but the significance of the regression coefficients is relatively low overall. Third, the results of the sub-samples of the other eight technical fields show that there is no significant change in the innovation difference between export firms and non-export firms before and after the Sino-US trade friction.

Overall, the heterogeneity test results show that the innovation performance of export firms in the advanced manufacturing industry is more prominent after being shocked by the Sino-US trade frictions. In addition, the observed value of advanced manufacturing 
firms entering the regression is 50,705, almost one-third of the national sample. Combined with the regression results of sub-samples in other technical fields, it can be inferred that the innovative effect of the Sino-US trade frictions on China's advanced manufacturing export firms is more evident.

\subsection{Export Grab Effect}

We hold that after the Sino-US trade friction, the export grab behaviour of firms has led to a significant increase in the innovation output of export firms after the shock. To verify the mechanism of the export grab effect affecting firm innovation, we first calculate the change in the average export situation of export firms in various technical fields from 2016 to 2019 according to the data used, compare the behaviour differences of export firms in different technical fields after the Sino-US trade friction, and verify that the "export grab" of firms following the Sino-US trade friction does exist from the microdata, especially for those firms in technical fields with prominent innovation output. Then, we construct relevant indicators to test the underlying mechanism by which export grabbing leads to firm innovation.

Table 6 shows the changes in export performance in various technical fields in the whole sample. After comparing the average export volume, export growth and the income share of exports, we find that first, on average, those firms in the technical fields that have significantly increased innovation have exceptionally prominent export performance after the Sino-US trade friction. Taking the advanced manufacturing industry as an example, before 2018, the average export volume remained at approximately 4600, and this index doubled in 2018 and soared to 13,708.90 in 2019. After the trade friction, it increased by 149\% compared with that before the trade friction. At the same time, in the above heterogeneity test, the average export volume of firms in technical fields with a significant increase in innovation showed outstanding growth. After the trade friction, the average export volume of firms in the modern transportation industry, biomedicine and medical devices and new materials increased by $103 \%, 72 \%$ and $112 \%$, respectively, while the average export growth of firms in other technical fields was comparatively slow, and even negative growth. Second, after the Sino-US trade friction, there has been a significant increase in innovative technology, and firms in the field have more export business growth, which is reflected in the obvious shift of firms' business focus to the export market. The last column of Table 6 calculates the changes in firms' average income share of exports in each technical field from 2017 to 2018. After comparing the indicators in different technical fields, we find that the technical fields with obvious innovation increases after the Sino-US trade friction have a relatively higher change in the income share of exports, which means that after the Sino-US trade friction, on average, firms in these technology fields are more inclined to increase export business. For example, in the most prominent advanced manufacturing industry, the average income share of exports in 2018 increased by $11.01 \%$ compared with that in 2017. Third, from the overall sample, after the Sino-US trade friction, the average export volume of firms increased by only $5 \%$, and the proportion of export business income decreased by $5.89 \%$. Obviously, those firms with negative trade growth after trade friction lowered the average export growth rate and the income share of exports, but this does not prevent us from seeing the existence of firms' export-grab behaviour through the heterogeneity of each technical field. 
Table 6. Changes in exports of various technical fields before and after the Sino-US trade friction.

\begin{tabular}{|c|c|c|c|c|c|c|c|}
\hline & \multirow[b]{2}{*}{2016} & \multicolumn{3}{|c|}{$\begin{array}{l}\text { Average Export Volume of Firms } \\
\text { (Unit: Thousand RMB) }\end{array}$} & \multirow{2}{*}{$\begin{array}{c}\text { Export } \\
\text { Growth } \\
\text { Before and } \\
\text { After Friction }\end{array}$} & \multirow{2}{*}{ Growth Rate } & \multirow{2}{*}{$\begin{array}{l}\text { Changes of } \\
\text { Export- } \\
\text { Income Ratio } \\
(2017-2018)\end{array}$} \\
\hline & & 2017 & 2018 & 2019 & & & \\
\hline $\begin{array}{l}\text { 1.Advanced } \\
\text { manufacturing } \\
\text { 2.Modern }\end{array}$ & 4614.58 & 4550.54 & 9120.90 & $13,708.90$ & $13,664.68$ & $149 \%$ & $11.01 \%$ \\
\hline $\begin{array}{l}\text { transportation } \\
\text { industry }\end{array}$ & 2569.67 & 595.88 & 2389.68 & 4045.35 & 3269.48 & $103 \%$ & $4.09 \%$ \\
\hline $\begin{array}{l}\text { 3.Biomedicine } \\
\text { and medical } \\
\text { devices }\end{array}$ & 7059.88 & 7082.30 & $10,664.42$ & $13,699.95$ & $10,222.19$ & $72 \%$ & $6.16 \%$ \\
\hline 4.New material & 3055.57 & 3957.21 & 6722.93 & 8155.40 & 7865.55 & $112 \%$ & $4.90 \%$ \\
\hline $\begin{array}{l}\text { 5.Electronic } \\
\text { information }\end{array}$ & $62,834.50$ & $41,128.35$ & $13,575.33$ & $42,553.66$ & $-47,833.86$ & $-46 \%$ & $-30.01 \%$ \\
\hline 6.Aerospace & 8552.50 & 7771.81 & 7425.47 & 4570.59 & -4328.25 & $-27 \%$ & $-1.45 \%$ \\
\hline $\begin{array}{l}\text { 7.New energy } \\
\text { and energy } \\
\text { conservation }\end{array}$ & 156.50 & 6289.41 & 4770.05 & 4034.61 & 2358.75 & $37 \%$ & $-5.16 \%$ \\
\hline $\begin{array}{l}\text { 8. Environmental } \\
\text { protection }\end{array}$ & 4246.35 & 2397.26 & 4796.42 & 3405.61 & 1558.42 & $23 \%$ & $4.19 \%$ \\
\hline All samples & $13,892.59$ & $13,010.03$ & 9747.74 & $18,548.90$ & 1394.02 & $5 \%$ & $-5.89 \%$ \\
\hline
\end{tabular}

Note: this table only shows the export changes of eight technical fields, as the other four technical fields are not listed in the table due to small sample size or obvious exceptionality.

The analysis of the results in Table 6 means that export grab behaviour does exist in some specific technical fields, and those fields happen to have outstanding innovation performance. On the one hand, the export grab behaviour of firms is reflected in the substantial growth of the average export volume of firms; on the other hand, it is reflected in the increase in the proportion of export business. These indicators show that export firms have increased their export business in the short term, and the increase is large. Although we cannot intuitively observe the export grab behaviour of firms, the real data still enable us to speculate that export grab behaviour does exist in some specific technical fields.

The export grab may be the reason for the increase in firm innovation in some of the technical field, especially for advanced manufacturing industry, since the innovation promoting effect of export has been widely discussed in the extant trade literature. The sudden expansion in exports may benefit firm innovation through several channels as we have stated in the literature review, including export learning effect $[21,32,35]$, cost reducing channel $[17,20]$, market competition effect $[9,11]$, reallocation effect $[11,16]$, etc. In the following section, we try to verify the promoting effect of export grab on firm innovation by doing a detailed empirical test, which may explain the increase in firm innovation following Sino-US trade friction as well as the prominent performance of firms in advanced manufacturing industry.

\subsection{Mechanism of the Export Grab Effect on Firm Innovation}

In fact, the phenomenon of export grab is a manifestation of the shock of foreign demand. The previous analysis also shows that the export grab phenomenon is the overdraft of foreign demand for the future, and its purpose is to avoid the risk of rising trade costs. Therefore, after the break of the Sino-US trade friction, foreign procurement has increased rapidly, which is reflected in the export grab phenomenon of the Chinese firms. There are two effects on the innovation of export firms. The first is the direct effect. The direct effect comes from the diminishing marginal cost caused by the production expansion of export firms after the impact of foreign demand. Therefore, firms will choose to update their technology after obtaining a productivity advantage [16,17]. Atkeson and Burstein believe that the ratio of a firm's export quantity to its output can represent the impact of the direct effect [16]. Because our data only provide information on firms' export volume and income, we use firms' export income share export_rate fit $_{\text {in }}$ to indicate the direct effect, which can be used to reflect the changes in the proportion of the firms' export business in the total 
business. The second is the indirect effect. The indirect effect comes from the reallocation of domestic export firms by the impact of foreign demand. This effect will reduce the export threshold and allocate exports to capable firms [11,20], which is manifested in the concentration of export market share to large firms, so the innovation of large firms is more obvious. We use the logarithm of the export volume of firms $\operatorname{lnexport}_{\text {fit }}$ to measure indirect effects.

\subsubsection{Direct Effect}

The direct effect of export grab on firm innovation comes from sustainable exporters. After the impact, due to the sharp increase in foreign demand, firms need to expand production and export relatively more products abroad in the short term, which is reflected in the increase in the proportion of the firm's export business. Therefore, this will reduce the marginal cost of production, and export firms will gain the advantage of productivity. In this case, firms will be likely to carry out innovation activities. To test the direct effect, we eliminate the samples of firms entering and exiting the export market after the Sino-US trade friction to fix the impact of the threshold of the export market on the results. In Column (1) of Table 7, the benchmark model is re-estimated with new samples, and the results show that the estimated coefficient of $E X P_{f i} * \operatorname{Post}_{t} 8_{t}$ is significantly positive, but its estimated coefficient of 0.044 is not only less than the level of 0.086 in the benchmark regression but also only $10 \%$ significant, which shows that after controlling the entry and exit threshold of the export market, sustainable export firms still increase innovation after the Sino-US trade friction, but the contribution of sustainable export firms to the overall innovation of export firms after the Sino-US trade friction may be relatively small. That is, the direct effect of export grab may be small. To further test the direct effect of export grab, we further add export_rate fit $_{\text {it }}$ to the regression, and the results are reported in Column (2) of Table 7. The estimated coefficient of $E X P_{f i} *$ Post $_{1} 8_{t}$ is lower than it is in Column (1) and is not significant. At the same time, the coefficient of export_rate fit $_{\text {it }}$ is significantly positive, which indicates that the significance of the estimated coefficient of $E X P_{f i} * \operatorname{Post}_{1} 8_{t}$ has been absorbed by the direct effect of export grab. This also means that the increase in sustainable export firms' innovation after the Sino-US trade friction can be explained by the direct effect of export grab. Therefore, combined with the results of Columns (1) and (2), it can be inferred that the direct effect of export grab is the mechanism of increasing innovation of export firms after the Sino-US trade friction.

To further test the existence of the direct effect of export grab, we retain only the firms that continue to export in the sample and use the method of long difference and two-stage least squares (2SLS) to verify the relationship between export grab and firm innovation again. The specific identification methods are as follows:

$$
D . \ln (\text { Innovation })_{f i, 2019-2017}=\gamma_{0}+\gamma_{1} \text { D.export_rate } f i, 2019-2017+X_{f i, 2017} * \gamma_{2}+\theta_{i}+\varepsilon_{f i}
$$

Among them, the explained variable, D.In(Innovation $)_{f i, 2019-2017}$, is the difference between firm innovation in 2019 and 2017, and the explanatory variable, D.export_rate $f_{i, 2019-2017}$, is the difference between the income share of exports of firms in 2019 and 2017. $X_{f i, 2017}$ is a series of control variables at the firm and industry levels in 2017. $\theta_{i}$ is the fixed effect of the industry, and $\varepsilon_{f i}$ is the residual term. The specific regression adopts the 2SLS method to calculate the income share of exports in 2017, export_rate $f i, 2017$, as the instrumental variable for export_rate ${ }_{f i, 2017}$.

The OLS regression results are shown in Column (3) of Table 7. The coefficient of

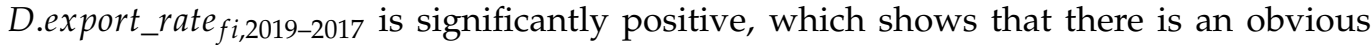
positive relationship between the direct effect of export grab and firm innovation. The more firms increase the proportion of export business after the Sino-US trade friction, the more inclined they are to have more innovation. Column (4) further uses the 2SLS method to estimate the model, and the results show that the coefficient of D.export_rate ${ }_{f i, 2019-2017}$ is significantly positive but slightly lower than that in Column (3). Therefore, combined with the estimation results of other columns in Table 7 , we can basically judge the existence of 
the direct effect of export grab. Export grabbing after the Sino-US trade frictions leads to an increase in the innovation of sustainable export firms. However, from the estimated results of this sample, the direct effect of export grab is relatively small.

Table 7. Mechanism test of the export grab effect promoting firm innovation (direct effect).

\begin{tabular}{|c|c|c|c|c|}
\hline & (1) & (2) & (3) & (4) \\
\hline & \multicolumn{2}{|c|}{$\ln (\text { Innovation })_{f i t}$} & \multicolumn{2}{|c|}{ D.ln(Innovation $)_{f i, 2019-2017}$} \\
\hline$E X P_{f i} *$ Post $18_{t}$ & $\begin{array}{l}0.044 * \\
(0.026)\end{array}$ & $\begin{array}{c}0.035 \\
(0.026)\end{array}$ & & \\
\hline export_rate ${ }_{\text {it }}$ & & $\begin{array}{c}0.320 * * * \\
(0.098)\end{array}$ & & \\
\hline D.export_rate $_{f i, 2019-2017}$ & & & $\begin{array}{c}0.531 \text { *** } \\
(0.190)\end{array}$ & $\begin{array}{c}0.705^{* *} \\
(0.287)\end{array}$ \\
\hline Control variables & yes & yes & yes & yes \\
\hline Individual FE & yes & yes & & \\
\hline Industry FE & & & yes & yes \\
\hline Year FE & yes & yes & yes & yes \\
\hline $\mathrm{N}$ & 12,7396 & 10,4905 & 672 & 672 \\
\hline $\mathrm{R}^{2}$ & 0.638 & 0.649 & 0.062 & 0.060 \\
\hline
\end{tabular}

Note: the direct effect of export grab comes from sustainable export firms. Therefore, Column (1) excludes the samples of newly entering and exiting export firms after the Sino-US trade friction to compare the changes in innovation of sustainable export firms before and after the friction. Column (2) further controls the variables of the direct effect mechanism. Therefore, it is found that the increase in innovation of export firms has been absorbed by the direct effect. Columns (3) and (4) only retain the samples of sustainable export firms and use the long difference method to estimate the direct effect of export grab, in which Column (3) is the OLS estimation result and Column (4) is the 2SLS estimation result. Column (1) and (2) control both individual and year fixed effects (FE). Column (3) and (4) control both industry and year fixed effects (FE). Standard errors are clustered at the four-digit code of the Chinese industry. ${ }^{* * *},{ }^{* *},{ }^{*}$ indicate significance levels of $1 \%, 5 \%$ and $10 \%$, respectively. $\mathrm{N}$ stands for the number of observations and $\mathrm{R}^{2}$ indicates the fitness of the model.

\subsubsection{Indirect Effects}

The indirect effect of export grab on the innovation of export firms comes from the impact of foreign demand, which changes the distribution of export firms. The positive demand shock reduces the threshold for firms to enter the export market. On the one hand, it will lead to more new export firms entering the export market, and the export learning effect increases firms' innovation. On the other hand, large-scale export firms will be allocated more export shares, and firms will be more capable of innovation. Both of these aspects are reflected in the increase in firm export volume. We use the intersection of the logarithm of the export volume and Post $18_{t}$ to represent the indirect effect mechanism and replace it with the explanatory variable of the benchmark regression to test the indirect effect of export grab. Its estimation coefficient represents the impact of the change in the export market threshold on firm innovation after the Sino-US trade friction. It should be noted that the above has verified the existence of the direct effect mechanism, and the direct effect may be reflected in the growth of enterprise export volume. Therefore, to avoid the interference of the direct effect of export grab on the identification of indirect effects, we further control the direct effect, specifically, adding the income share of exports in the regression to control the direct effects of sustainable export firms.

Table 8 shows the test results of the indirect effect mechanism of export grab to promote firm innovation. Column (1) is the full sample regression result. The estimation coefficient of $E X P_{f i} *$ Post $18_{t}$ is significantly positive, which means that after the Sino-US trade friction, firms with an expanded export scale have better innovation output. That is, on average, there is an indirect effect on firm innovation. At the same time, the estimated coefficient of the direct effect variables is also significantly positive, which once again verifies the existence of the direct effect of export grab, but the direct effect fails to absorb the indirect effect. To deeply verify the existence of the indirect effect mechanism and test the heterogeneity effect of the mechanism, Columns (2)-(5) of Table 8 also report the regression results of samples in different technical fields and select four representative technical fields, namely, advanced manufacturing industry, modern transportation industry, 
electronic information and new energy and energy conservation. This is because the results in Table 6 show that there is an obvious phenomenon of export grab in advanced manufacturing and modern transportation industries, while there is an obvious trade contraction in the fields of electronic information, new energy and energy conservation. Comparing the regression results of these four technical fields can test the difference in innovation between the technical fields with and without export grab, and further verify the effect of export grab on enterprise innovation. Column (2) gives the regression results of the advanced manufacturing sub-samples. The estimated coefficient of lnexport $_{f i t} * \operatorname{Post}_{1} 8_{t}$ is significantly positive, which shows that the indirect effect of export grab has an obvious promoting effect on the innovation of export firms. Column (3) reports the sub-sample regression results of the modern transportation industry. Therefore, under the sub-sample of the modern transportation industry, the indirect effect of export grab has a positive effect on the innovation of export firms. Columns (4) and (5) are the regression results of electronic information and new energy and energy conservation sub-samples, respectively. The estimated coefficients of lnexport $_{\text {fit }} *$ Post $_{18}{ }_{t}$ are not significant, which shows that there is no indirect effect of export grab in these two technical fields.

Table 8. Mechanism test of the export grab effect promoting firm innovation (indirect effect).

\begin{tabular}{|c|c|c|c|c|c|}
\hline & (1) & (2) & (3) & (4) & (5) \\
\hline \multirow{3}{*}{ Inexport $_{f i t} *{\text { Post } 18_{t}}_{t}$} & Total Sample & $\begin{array}{c}\text { Advanced } \\
\text { Manufacturing }\end{array}$ & $\begin{array}{c}\text { Modern } \\
\text { Transportation } \\
\text { Industry }\end{array}$ & $\begin{array}{c}\text { Electronic } \\
\text { Information }\end{array}$ & $\begin{array}{c}\text { New Energy and } \\
\text { Energy } \\
\text { Conservation }\end{array}$ \\
\hline & $0.013^{* * *}$ & $0.014^{* * *}$ & $0.091^{* *}$ & 0.006 & 0.013 \\
\hline & $(0.003)$ & $(0.005)$ & $(0.035)$ & $(0.007)$ & $(0.022)$ \\
\hline \multirow[t]{2}{*}{ export_rate $_{\text {fit }}$} & $0.258^{* *}$ & 0.043 & -0.762 & $0.443^{* *}$ & 0.902 \\
\hline & $(0.100)$ & $(0.155)$ & $(0.895)$ & $(0.210)$ & $(0.714)$ \\
\hline Control variables & yes & yes & yes & yes & yes \\
\hline Individual FE & yes & yes & yes & yes & yes \\
\hline Year FE & yes & yes & yes & yes & yes \\
\hline $\mathrm{N}$ & 109,337 & 43,425 & 790 & 20,569 & 3750 \\
\hline $\mathrm{R} 2$ & 0.651 & 0.661 & 0.726 & 0.658 & 0.687 \\
\hline
\end{tabular}

Note: lnexport $_{\text {fit }}$ is the logarithm of the firm's export volume, which is multiplied by Post $18_{t}$ to form an explanatory variable. Column (1) is the full sample regression result, and Columns (2)-(5) are the sub sample regression results in the fields of advanced manufacturing, modern transportation, electronic information, new energy and energy conservation. All regressions controlled for direct effects. All regressions control both individual and year fixed effects (FE). Standard errors are clustered at the four-digit code of the Chinese industry. $* * * * *$ indicate significance levels of $1 \%$ and $5 \%$, respectively. $\mathrm{N}$ stands for the number of observations and $\mathrm{R}^{2}$ indicates the fitness of the model.

Overall, the indirect effect of export grab explains the increase in innovation of export firms after the Sino-US trade friction. Due to the shock of foreign demand, the threshold for export firms to enter foreign markets has been reduced, which is manifested in the allocation of export volume to large firms, and new export firms have entered the market, which has promoted the innovation of export firms on average. By horizontally comparing the regression results of the columns in Table 8, it can be found that the indirect effect of export grab exists in the technical field where there is an obvious phenomenon of export grab, and the innovation of export firms in the technical fields where there is no export grab has not increased significantly after the Sino-US trade friction, which also verifies the role of export grab in promoting firm innovation on one side.

\section{Concluding Remarks}

This paper studies the short-term impact of the Sino-US trade frictions on China's firm innovation. By using the unique microdata of Chinese technology and innovation firms from 2016 to 2019, we find that the innovation of technological and innovative export firms has, on average, increased significantly after being impacted by the Sino-US trade friction, which contradicts the extant theoretical literature. For example, in the seminal 
work of Handley and Limão, the disappearance of trade policy uncertainty caused by the removal of tariff will promote technical upgrading [5], so the Sino-US trade friction will not be conducive to the growth of firm innovation, while aggravating trade policy uncertainty. Through the in-depth investigation of firm operational data, we also exclude the escaping competition effect induced by shocks in export market that might compel firms to innovate [11]. Therefore, external market export pressure, as it has been discussed in the literature $[8,12]$, is not the reason for the increase in firm innovation in our case.

Through further study of sub-samples in different technical fields, we find that the advanced manufacturing industry has outstanding performance after the Sino-US trade frictions. The analysis results of the sub-samples of 12 technical fields in the sample show that the innovation of export firms in the advanced manufacturing industry is the most obvious in various technical fields, and the export firms in the modern transportation industry, biomedicine and medical devices, and new materials have also increased to varying degrees after the Sino-US trade friction. To explore the reasons for the innovative growth of export firms after the Sino-US trade friction, we conduct an in-depth investigation of the operations of firms and find that the technical fields that have increased innovation after the trade friction often have significant export business growth. Therefore, we speculate that export grab is the reason for the innovation growth of export firms after the Sino-US trade friction and test for it. Theoretically, export grab is the demand impact of foreign markets. Export grab has direct and indirect effects on the innovation of export firms. The direct effect is the productivity advantage brought by the decline of marginal cost after the impact, and the indirect effect is the reallocation effect brought by the impact on the adjustment of the threshold for firms to enter the export market. Both effects may lead to an increase in firm innovation. We construct indicators to verify the direct effect and indirect mechanism of export grab induced by the Sino-US trade friction on firm innovation. In line with the present research $[11,16]$, we once again verified the great significance of export to firm innovation.

The limitation of this article is that we cannot test the long-term effect of the Sino-US trade friction on firm innovation due to the short-period data we used. The phenomenon of export grab is a relatively short response of exporters to the outbreak of the Sino-US trade friction. The economic relationship between China and the US has not been restored, which continues to impact on firm performance of both countries. Therefore, as the effect of export grab gradually fades, the long-term impact of the Sino-US trade friction on firm innovation may be different from what we have seen today.

In addition to the above long-term effect, there are some issues related to this paper that deserve attention. First, to study the new mechanism of the Sino-US trade friction on firm innovation. Although we have found that the export grab is a short-term channel through which the Sino-US trade friction affects firm innovation, we believe that there are more potential channels need to be found. Second, to study the effect of the Sino-US trade friction on the economic activities in other countries. Since the beginning of 2018, the Sino-US trade friction has been reallocating the international commodity market. Future research can focus on the impact of the Sino-US trade friction on economic activities in countries including but not limited to China and the US.

Author Contributions: Conceptualization, Z.X. and X.Z.; methodology Z.X.; software, Z.X.; formal analysis, Z.X., X.Z. and Z.Z.; resources, Z.Z.; data curation, Z.X. and Z.Z.; writing-original draft preparation, Z.X.; writing-review and editing, Z.X. and X.Z.; supervision, X.Z. All authors have read and agreed to the published version of the manuscript.

Funding: This research received no external funding.

Institutional Review Board Statement: Not applicable.

Informed Consent Statement: Not applicable.

Data Availability Statement: The data presented in this study are available on request from the corresponding author. The data are not publicly available due to privacy. 
Acknowledgments: We are grateful to the helpful comments from Mi Dai, Guangming Ma, Xiufei Ding, Ke Ma, Hui Wang and Jingchen Jin.

Conflicts of Interest: The authors declare no conflict of interest.

\section{References}

1. Schumpeter, J.A. The Theory of Economic Development; Harvard University Press: Cambridge, MA, USA, 1932.

2. Handley, K.; Limão, N. Trade Under, T.R.U.M. P Policies. In Economics and Policy in the Age of Trump; Bown, C.P., Ed.; CEPR Press: Colchester, UK, 2017.

3. Handley, K. Exporting Under Trade Policy Uncertainty: Theory and Evidence. J. Int. Econ. 2014, 94, 50-66. [CrossRef]

4. Handley, K.; Limão, N. Policy Uncertainty, Trade and Welfare: Theory and Evidence for China and the U.S. Am. Econ. Rev. 2017, 107, 2731-2783. [CrossRef]

5. Handley, K.; Limão, N. Trade and Investment Under Policy Uncertainty: Theory and Firm Evidence. Am. Econ. Rev. 2015, 7, 189-222. [CrossRef]

6. Tong, J.D.; Li, S.Q. Effect of Trade Policy Uncertainty on Export Enterprises' Product Innovation. Int. Trade Issues 2016, 6, 25-32.

7. Liu, Q.; Ma, H. Trade Policy Uncertainty and Innovation: Firm Level Evidence from China' WTO Accession. J. Int. Econ. 2020, 127, 103387. [CrossRef]

8. Galdon-Sanchez, J.E.; Schmitz, J., Jr. Competitive Pressure and Labor Productivity: World Iron-Ore Markets in the 1980's. Am. Econ. Rev. 2002, 92, 1222-1235. [CrossRef]

9. Aghion, P.; Bloom, N.; Blundell, R.; Griffth, R.; Howitt, P. Competition and Innovation: An Inverted-U-Relationships. Q. J. Econ. 2005, 120, 701-728.

10. Aghion, P.; Blundell, R.; Griffith, R.; Howitt, P.; Prantly, S. The Effects of Entry on Incumbent Innovation and Productivity. Rev. Econ. Stat. 2009, 91, 20-32. [CrossRef]

11. Aghion, P.; Bergeaud, A.; Lequien, M.; Melitz, M. The Heterogeneous Impact of Market Size on Innovation: Evidence from French Firm-Level Exports; Working Paper; Harvard University: Cambridge, MA, USA, 2019.

12. Raith, M. Competition, Risk, and Managerial Incentives. Am. Econ. Rev. 2003, 93, 1425-1436. [CrossRef]

13. Xie, J.G.; Wang, X. The Trade Consequences of the Sino-US Trade Conflict: An Empirical Research Based on Segmented Product Data. Theory Pract. Financ. Econ. 2021, 42, 86-93.

14. Zhang, W.T.; Xu, R.H.; Wang, Q. The Impact of Sino-US Trade Friction on China' Exports from Uncertainty. Theory Pract. Financ. Econ. 2020, 3, 111-118.

15. Cavallo, A.; Gopinath, G.; Neiman, B.; Tang, J. Tariff Passthrough at the Border and at the Store: Evidence Form Us Trade Policy; NBER Working Papers No 26396; National Bureau of Economic Research, Inc.: Cambridge, MA, USA, 2019. [CrossRef]

16. Atkeson, A.; Burstein, A. Innovation, Firm Dynamics, and International Trade. J. Political Econ. 2010, 118, 433-484. [CrossRef]

17. Bustos, P. Trade Liberalization, Exports, and Technology Upgrading: Evidence on the Impact of MERCOSUR on Argentinian Firms. Am. Econ. Rev. 2011, 101, 304-340. [CrossRef]

18. Wei, M.H.; Liu, X.M. Trade-related Environmental Uncertainty and Firm's Innovation: Evidence from Chinese Listed Firms. Nankai Manag. Rev. 2021, 24, 16-25.

19. Wan YX Wei, Z.X.; Wang, Y.S. Does China-US Trade Dispute Affect Chinese Firms' R\&D Internationalization. Stud. Sci. Sci. 2021; submitted for publication.

20. Lileeva, A.; Trefler, D. Improved Access to Foreign Markets Raises Plant-Level Productivity for Some Plants. Q. J. Econ. 2010, 125, 1051-1099. [CrossRef]

21. De-Loecker, J. Do Exports Generate Higher Productivity? Evidence from Slovenia. J. Int. Econ. 2007, 73, 69-98. [CrossRef]

22. Fajgelbaum, P.D.; Goldberg, P.; Kennedy, P.; Khandelwal, A. The Return to Protectionism. Q. J. Econ. 2020, 135, 1-54. [CrossRef]

23. List, F. The National System of Political Economy; OLL: London, UK, 1841.

24. Krugman, P. Rethinking International Trade; MIT Press: Cambridge, MA, USA, 1990.

25. Brezis, E.S.; Krugman, P.; Tsiddon, D. Leapfogging in International Competition: A Theory of Cycles in National Technological Leadership. Am. Econ. Rev. 1993, 83, 1211-1219.

26. Krugman, P. A Model of Innovation, Technology Transfer, and the World Distribution of Income. J. Political Econ. 1979, 87, 253-256. [CrossRef]

27. Dollar, D. Technological Innovation, Capital Mobility and the Product Cycle in North-South Trade. Am. Econ. Rev. 1986, 76, 177-190.

28. Li, C.D.; He, C.T.; Lin, C.W. Evaluating the Effects of China's Countermeasures to China-U.S. Trade Frictions. China Ind. Econ. 2018, 10, 137-155.

29. Lv, Y.; Lou, C.R.; Du, Y.X.; Tu, X.Q. An Analysis of the Impact of Sino-US Trade Friction Based on the Tariff Lists. J. Financ. Econ. 2019, 45, 59-72.

30. Cui, L.B.; Zhu, L.; Song, M.L.; Zheng, H.T. The Economic Evaluation of China-US Trade Frictions. J. Financ. Econ. 2018, 44, 4-17.

31. Amiti, M.; Redding, S.J.; Weinstein, D.E. The Impact of the 2018 Tariffs on Prices and Welfare. J. Econ. Perspect. 2019, 33, 187-210. [CrossRef] 
32. Van Biesebroeck, J. Exporting Raises Productivity in Sub-Saharan African Manufacturing Firms. J. Int. Econ. 2005, 67, 373-391. [CrossRef]

33. Zhang, J.; Li, Y.; Liu, Z.B. Does Export Promote the Productivity of Chinese Firms? Empirical Evidence from Chinese Local Manufacturing Firms: 1999-2003. Manag. World 2009, 12, 50-64.

34. Melitz, M.J. The Impact of Trade on Intra-Industry Reallocations and Aggregate Industry Productivity. Econometrica 2003, 71, 1695-1725. [CrossRef]

35. De Loecker, J. Detecting Learning by Exporting. Am. Econ. J. Microecon. 2013, 5, 1-21. [CrossRef]

36. Hanley, A.; Perez, J.M. Are Newly Exporting Firms More Innovative? Findings from Matched Spanish Innovator. Econ. Lett. 2012, 116, 217-220. [CrossRef]

37. Li, B.; Yue, Y.S.; Chen, T. Export and Innovation: Empirical Evidence from Patent Data at Firm Level. World Econ. 2016, 39, 72-94.

38. Shi, Q.; Li, P.; Zong, Q.Q. Learning by Exporting: From the Perspective of Enterprise R \& D Strategy Interaction. World Econ. 2017, 40, 72-97.

39. Aw, B.Y.; Roberts, M.J. Productivity and Turnover in the Export Market: Micro-Level Evidence from the Republic of Korea and Taiwan (China). World Bank Econ. Rev. 2000, 14, 65-90. [CrossRef]

40. Dai, M.; Yu, M. Firm R\&D, Absorptive Capacity and Learning by Exporting: Firm-level Evidence from China. World Econ. 2013, 36, 1131-1145. 